\title{
PEMANFAATAN SUMBER DAYA AIR DAS YEH PENET SEBAGAI AIR IRIGASI DAN AIR BAKU PDAM
}

\author{
I Made Mudiasa ${ }^{1}$, IG. B. Sila Dharma ${ }^{2}$,I Ketut Suputra ${ }^{2}$
}

\begin{abstract}
Abstrak : Tukad (sungai) Penet, merupakan salah satu sungai terbesar di Provinsi Bali yang dimanfaatkan untuk keperluan pertanian, dan kebutuhan air bersih. Dengan berkembangnya kebutuhan akan air untuk berbagai sektor seperti irigasi dan air minum saat ini, pemanfaatan air sungai Penet mengalami ekspolitasi yang berlebihan sehingga tidak jarang terjadi sengketa antara petani yang memakai air untuk irigasi dan pengguna lainnya. Untuk itu diperlukan adanya kajian tentang pemanfaatan air sungai Penet untuk melihat berapa besar potensi yang dapat di exploitasi untuk pemenuhan kebutuhan akan sumber daya air. Analisis optimalisasi pemanfaatan air dilakuan pada enam Daerah Irigasi (DI) yang memanfaatkan air sungai Penet yaitu DI Peneng, DI, Luwus carang sari ,DI Kacangan, DI Penarungan, DI Kapal dan DI Munggu. Analisis optimasi didasarkan atas pola tanam, jadwal tanam dan pengaturan air serta kebutuhan maksimum air baku PDAM Kabupaten Tabanan dan Kabupaten Badung. Berdasarkan hasil simulasi, ketersediaan air pada di masing-masing DI sangat tergantung dari jadwal tanam dan pola tanam. Fluktuasi debit sungai memerlukan adanya pengaturan jadwal tanam dan sistem rotasi untuk beberapa daerah irigasi. Neraca air irigasi yang deficit terjadi pada DI Peneng, DI Luwus carangsari dan DI Kacangan. Optimasi air irigasi pada ke tiga daerah irigasi tersebut dilakukan dengan menggunakan simulasi jadwal tanam dan pengaturan air. Hasil analisis neraca air DAS pada bagian hilir DAS Yeh Penet menunjukan ketersediaan yang surplus pada alternatif jadwal tanam I dan II. Ketersediaan air Analisis neraca air dengan alternatif jadwal tanam I minimum 0.04 juta $\mathrm{m}^{3}$ dan maksimum $1.43 \mathrm{juta}^{3}$, sedangkan pada alternatif jadwal tanam II ketersediaan air sisa minimum 0.25 juta $^{3}$ dan maksimum 1.51 juta $\mathrm{m}^{3}$. Pengembangan potensi DAS Yeh Penet pada alternatif jadwal tanam I rata-rata sebesar $0.67 \mathrm{juta}^{3}$ $\left(0.52 \mathrm{~m}^{3} /\right.$ detik) dan pada alternatif jadwal tanam II rat-rata 0.76 juta $\mathrm{m}^{3}\left(0.58 \mathrm{~m}^{3} /\right.$ detik $)$ belum mampu memenuhi kebutuhan air total pada Kabupaten Badung dan Kabupaten Tabanan. Selain itu, pengembangan sumber daya air DAS Yeh Penet hanya dapat dilakukan pada bagian hilir dari sungai Yeh Penet untuk menghindari konflik kepentingan pemanfaatan air di DAS Yeh Penet.
\end{abstract}

Kata kunci: Optimalisasi, Pengembangan, Daerah irigasi, PDAM

\section{DEVELOPMENT OF WATER SOURCE IN FLOW AREA Of YEH PENET RIVER}

\begin{abstract}
Tukad Penet is one of the biggest rivers in Bali which is used to support farming and fresh water demand. The increasing of water demand in various sectors such as for irrigation and drink water recently using water from Yeh Penet source shows the over use of its water has caused some conflicts between the use of the water user for irrigation and another use. Therefore, it was needed to review the use of Yeh Penet water to see how big the potential of its water that could be exploited to support the water source demand. The optimal analysis of water usage was carried out in six regional irrigation (DI) used Penet river water such as DI Peneng, DI Kacangan, DI Luwuscarang Sari, DI Penarungan, DI Kapal and DI Munggu. This analysis was based on cropping, planting and water management as well as a maximum water raw demand of the regional company of drinking water (PDAM) in Tabanan and Badung regency. Based on the simulation result, water availability in each irrigation regional $(D I)$ depended on the cropping and planting. It was needed to provide the planting and rotation system for some irrigation regionals in river fluctuation discharge. The deficit of irrigation water balance occurred in DI Peneng, DI Luwuscarang sari, and DI Kacangan. The optimal use of irrigation water in the third irrigation regional was carried out by using planting stimulation and water management. The water balance analysis result at watershed in the part of downstream Penet watershed showed the availability of water surplus occurred in alternative plan I and II. The water balance analysis showed water availability in alternative plan I of a minimum 0.04 million $\mathrm{m}^{3}$ and maximum 1.43 million $\mathrm{m}^{3}$, whereas in alternative plan II the wasted water availability of a maximum 0.25 million $\mathrm{m}^{3}$ and a maximum 1.51 million $\mathrm{m}^{3}$. The potential development of Penet watershed in alternative plan I was 0.67 million $\mathrm{m}^{3}\left(0.52 \mathrm{~m}^{3} / \mathrm{sec}\right)$ and in alternative plan II was 0.76 million $\mathrm{m}^{3}(0.58$ $\mathrm{m}^{3} / \mathrm{sec}$ ) was not able to support the total water demand in Badung and Tabanan regency. Besides, the water source development of Penet watershed only occurred in downstream part of Yeh Penet river to avoid some conflicts of water utilization in Penet watershed.
\end{abstract}

Keyword : Optimalitation, development, irrigation area, regional company of drinking water (PDAM)

\footnotetext{
${ }^{1}$ Mahasiswa Program Magister Teknik Sipil, Fakultas Teknik, Universitas Udayana, Denpasar.

${ }^{2}$ Staf Pengajar Program Magister Teknik Sipil, Fakultas Teknik, Universitas Udayana, Denpasar.
} 


\section{PENDAHULUAN}

Peningkatan kebutuhan air bersih akibat dari peningkatan jumlah penduduk, kunjungan wisatawan, pembangunan fasilitas pendukung pariwisata dan pembangunan pemungkiman baru di Provinsi Bali menyebabkan terjadinya kekurangan air bersih untuk pemenuhan kebutuhan tersebut (Kompas, 2011). Selain itu, tidak meratanya distribusi air bersih dan peningkatan kebutuhan air untuk berbagai keperluan menyebabkan terjadinya ekploitasi sumber daya air khususnya sumber daya air sungai di Provinsi Bali. Eksploitasi Sumber Daya Air (SDA) sungai disebabkan oleh potensi SDA sungai di Provinsi Bali merupakan yang terbesar dibandingkan dengan sumber daya air yang lainnya, akan tetapi distribusi SDA sungai yang ada tidak merata di seluruh wilayah di Provinsi Bali (Bappeda, 2013). Yeh Penet merupakan salah satu sungai yang mempunyai aliran sepanjang tahun dan memiliki potensi terbesar ketiga di Wilayah Sungai (WS) BaliPenida. Berdasarkan berita harian Bali Post tahun 2008, pemanfaatan potensi air Yeh Penet sebagai Sistem Penyediaan Air Minum (SPAM) penunjang kebutuhan air baku pada jaringan Sarbagita (Denpasar, Badung, Gianyar dan Tabanan).

Daerah Aliran Sungai (DAS) merupakan suatu kesatuan ekosistem dimana organisme dan lingkungannya berinteraksi secara dinamik dan memiliki ketergantungan satu sama lain dalam setiap komponennya (Asdak, 2002). Sehingga diperlukan penyeimbangan antara potensi sumber daya air yang ada dengan pemanfaatannya (Kodoatie, 2005). Pengembangan merupakan sarana penyeimbangan pemanfataan dan ketersediaan air (Triatmojo, 2009). Selain itu, Yeh Penet merupakan salah satu kawasan strategis dari sudut kepentingan fungsi dan daya dukung lingkungan hidup sesuai dengan peraturan daerah Provinsi Bali tahun 2009. Oleh karena itu, diperlukan pengembangan potensi DAS Yeh Penet yang bertujuan untuk menyeimbangkan antara ketersediaan dengan pemakaian air baik untuk irigasi maupun non irigasi (PDAM). Sehingga dapat menghindari konflik kepentingan antar sektor pemanfaatan potensi DAS Yeh Penet.

Berdasarkan uraian diatas, maka tujuan dari penelitian ini adalah untuk mengkaji keseimbangan pemanfaatan dan ketersediaan air di DAS Yeh Penet sebagai dasar rencana pengembangan sumber air, serta membuat simulasi optimasi alokasi air irigasi dan mengkaji besarnya pengembangan sumber daya air untuk kepeluan air baku domestik PDAM.

Hasil penelitian ini diharapkan dapat memberikan informasi ketersediaan sumber daya air, berapa besar kebutuhan air untuk irigasi dan alokasi air untuk keperluan non irigasi di DAS Yeh Penet. Selain itu, dapat dipergunakan sebagai referensi bagi instansi yang menangani pengembangan sumber daya air khususnya pada wilayah sungai yang ada di Provinsi Bali

\section{PREDIKSI KEBUTUHAN AIR}

\section{Debit Andalan}

Debit andalan adalah debit yang diharapkan selalu tersedia sepanjang tahun dengan resiko kegagalan yang diperhitungkan sekecil mungkin. Data debit andalan pada umumnya diperlukan untuk perencanaan pengembangan air irigasi, air baku dan pembangkit listrik tenaga air, yaitu untuk menentukan perhitungan persediaan air pada bangunan pengambilan. Agar mendapatkan perhitungan debit andalan yang baik, untuk itu diperlukan data pencatatan debit dengan jangka waktu yang panjang, hal ini dapat mengurangi terjadinya penyimpangan data perhitungan yang terlalu besar. Salah satu cara perhitungan debit andalan adalah menggunakan metode Rangking. Metode Rangking dilakukan berdasarkan pencatatan data debit dengan konsentrasi waktu yang cukup panjang. Selanjutnya data tersebut disusun atau dirangking mulai dari urutan data debit yang terkecil ke urutan terbesar. Setelah data diurutkan terlebih dahulu ditetapkan persentase debit andalan yang di harapkan. Debit andalan untuk keperluan irigasi ditetapkan $80 \%$ maka perumusan yang dipakai untuk menghitung debit andalan adalah (Nugroho,2011):

$\mathrm{M}=0.2 \times \mathrm{N}$

Keperluan air baku debit yang diharapkan tersedia adalah $99 \%$

$\mathrm{M}=0.01 \times \mathrm{N}$

Untuk keperluan air industry debit yang diharapkan tersedia adalah $95 \%$

$\mathrm{M}=0.05 \times \mathrm{N}$

Debit andalan untuk PLTA debit yang diharapkan tersedia adalah $90 \%$

$\mathrm{M}=0.1 \times \mathrm{N}$

Dimana:

M: Rangking debit andalan yang diharapkan

$\mathrm{N}$ : Jumlah tahun data pengamatan debit

\section{Neraca air}

Neraca air dipergunakan untuk menerangkan aliran air yang masuk dan aliran yang keluar pada suatu sistem.Pada perhitungan neraca air sebenarnya ada beberapa parameter-parameter yang sulit untuk diukur di lapangan terutama yang berhubungan dengan parameter air tanah, tetapi dalam perumusannya sering dilakukan penyederhanaan sesuai dengan kondisi lapangan 
setempat. Tujuan menghitung neraca air adalah sebagai berikut:

Menghitung persediaan air permukaan tanah dan sub permukaan tanah. Menaksir pola penggunaan air yang tersedia. Membantu untuk menyeimbangkan jumlah air yang lebih dan kekurangan air. Sebagai dasar perhitungan perencanaan optimasi pada manajemen sumber daya air. Pada prinsipnya persamaan neraca air didasarkan pada konsep continuity sebagai berikut:

$\mathrm{I}-\mathrm{O}=\mathrm{S}$

Dimana I merupakan inflow pada suatu system, O merupakan outflow pada suatu system dan $\mathrm{S}$ merupakan perubahan simpanan air.

\section{Kebutuhan air}

Kebutuhan air irigasi sebagian besar di cukupi dari air permukaan. Kebutuhan air irigasi dipengaruhi berbagai faktor seperti klimatologi, kondisi tanah, koefisien tanaman, pola tanam, pasokan air yang diberikan, luas daerah irigasi,efisiensi irigasi, penggunaan kembali air drainase untuk irigasi, sistem golongan, jadwal tanam dan lainnya. Kebutuhan air irigasi dihitung dengna persamaan (Triatmojo,2009):

$\mathrm{KAI}=\left(\frac{\mathrm{Etc}+\mathrm{IR}+\mathrm{WLR}+\mathrm{p}-\mathrm{Re}}{\mathrm{IB}}\right) \times \mathrm{A}$

Dimana :

KAI : Kebutuhan air irigasi $(1 / d)$

Etc : Kebutuhan air konsumtif ( $\mathrm{mm} /$ hari)

IR :Kebutuhan air ditingkat persawahan (mm/hari)

WLR: Kebutuhan air menganti lapisan air (mm/hari)

$\mathrm{P} \quad$ : Perkolasi (mm/hari)

Re : Hujan Efektif (mm/hari)

IE : Efisiensi Irigasi (\%)

A : Luas Areal Irigasi (Ha)

\section{Kebutuhan air domestik}

Kebutuhan air domestik di hitung berdasarkan jumlah penduduk dan kebutuhan air perkapita. Kriteria penentuan kebutuhan air dikeluarkan oleh Puslitbang Pengairan Departemen Pekerjaan Umum dengan menggunakan parameter jumlah penduduk sebagai penentuan jumlah air yang dibutuhkan perkapita per hari. Adapun kriteria tersebut dapat dilihat pada tabel 1
Tabel 1 Kriteria Penentuan

\begin{tabular}{cccc}
\hline $\begin{array}{c}\text { Jumlah } \\
\text { Penduduk }\end{array}$ & $\begin{array}{c}\text { Domestik } \\
(1 / \text { kapita/hr })\end{array}$ & $\begin{array}{c}\text { Non } \\
\text { Domestik } \\
(1 / \text { kapita/hr })\end{array}$ & $\begin{array}{c}\text { Kehilangan } \\
\text { Air } \\
(1 / \text { kapita/hr })\end{array}$ \\
\hline$>1.000 .000$ & 150 & 60 & 50 \\
\hline $\begin{array}{c}500.000- \\
1.000 .000\end{array}$ & 135 & 40 & 45 \\
\hline $\begin{array}{c}100.000- \\
500.000\end{array}$ & 120 & 30 & 40 \\
\hline $\begin{array}{c}20.000- \\
100.000\end{array}$ & 105 & 20 & 30 \\
\hline$<20.000$ & 82.5 & 10 & 24 \\
\hline
\end{tabular}

Sumber: Dep. Kimpraswil (2003)

\section{Optimasi}

Berapa bentuk teknik optimasi pegnembangan sumberdaya air yang ada didalam suatu DAS ialah, kalkulus, program linier, program tidak linier, program dinamik, simulasi dan lainnya (Sudjarwadi, 1987). Teknik Optimasi digunakan untuk memberikan hasil terbaik dari hal yang terburuk atau hal yang terbaik, tergantung masalah yang dihadapi. Hasil Optimasi mungkin hasil tertinggi (misalnya keuntungan) atau hasil terendah (misalnya kerugian). Optimasi memerlukan strategi yang bagus dalam mengambil keputusan agar diperoleh hasil yang optimum. Adapun dasar pengambilan keputusan pada teknik optimasi adalah sebagai berikut:

a. Berati memilih alternatif, yang jelas harus alternatif yang terbaik (the best alternative).

b. Terletak dalam perumusan berbagai alternatif tindakan sesuai dengan yang sedang dalam perhatian dan dalam pemilihan alternatif yang tepat, setelah suatu evaluasi/penilaian mengenai efektifitasnya dalam mencapai tujuan yang dikehendaki dalam mengambil keputusan.

Loucks (1981) mengemukankan bahwa teknik simulasi adalah sebuah metode yang efektif untuk mengevaluasi target alokasi penggunaan air yang relatif sederhana dibandingkan model lainnya. Sudjarwadi (1987) mengemukakan bahwa meode simulasi mempunyai magsud memproduksi watak esensial dari sistem yang ada dipelajari, watak sistem yang sesunguhnya ditiru, kemudian dipelajari dalam waktu yang singkat. Program simulasi dapat dibayangkan sebagai percobaan (eksperimen) penyelesaian masalah untuk mempelajari sistem yang komplek yang tidak dapat dianalisa secara langsung dengan cara analitik. Klarifikasi perilaku dan karakteristik sistem atau subsistem sumberdaya air secara kuantitatif untuk menyiapan data masukan guna analisis lebih lanjut terkait dengan upaya pemanfaatan sumberdaya air. 


\section{METODE}

Pendekatan dalam penelitian ini mempergunakan model deskritif kuantitatif, sehingga dapat memberikan gambaran ketersediaan air dengan pemanfaatan air di daerah aliran sungai Yeh Penet. Penggunan data primer seperti pengamatan lapangan dan data sekunder berupa study literature dipergunakan untuk memberikan alternatif-alternatif pengembangan sumber daya air di daerah aliran sungai Yeh Penet. pemilihan alternatif pemanfaatan air untuk keperluan irigasi diharapkan dapat memberikan ketersediaan air yang surplus dan pengoptimalan pemanfaatan air sisa pemakaian irigasi. Optimasi pemanfaatan air irigasi dipergunakan untuk pengoptimalan pemanfaatan luas lahan yang tersedia dengan ketersediaan air yang ada. Teknik optimasi air irigasi pada penelitian ini mempergunakan simulasi alternatif jadwal tanam, pengaturan air dan pengaturan pola tanam. Asumsi simulasi alternatif jadwal tanam mempergunakan pendekatan ketersediaan debit yang tersedia untuk dapat pengoptimalan pemanfaatan air dengan luas lahan yang tersedia. Pengaturan air dipergunakan apabila ketersediaan air pada alternatif simulasi jadwal tanam masih deficit. Pengaturan air dilakukan dengan menggunakan system rotasi pemakaian air dalam periode waktu tertentu dengna pertimbangan luas lahan yang dialiri air saling berdekatan di masing-masing golongan. Namun, apabila ketersediaan air lebih kecil dari pemakaian air irigasi, maka optimasi pemanfaatan air dilakukan dengan mepergunakan pengaturan pola tanam.

Pengembangan sumber daya air merupakan penyeimbangan antara pemakaian air dengan ketersediaan air. Dalam penelitian ini, pengembangan SDA di daerah aliran sungai Yeh Penet diperuntukan untuk pemakaian air baku PDAM untuk penunjang Sarbagita. Pengembangan SDA di daerah aliran sungai Yeh Penet diprioritaskan pada bagian hilir sungai Yeh Penet untuk mengindari konflik kepentingan pemanfaatan air pada bagian hulu. Analisis neraca air daerah aliran sungai akan memberikan nilai besarnya debit sungai Yeh Penet yang dapat di kembangkan untuk keperluan air baku PDAM pada bagian hilir.

Pengembangan sumber daya air terdiri dari pemanfaatan air dan pengaturan air. Pengembangan wilayah sungai merupakan pengusahaan kesejateraan umum melalui cara pengembangan sumber daya air secara optimal. Pengembangan sumber daya air memiliki cirri-ciri yang didasarkan pada pemanfaatan secara terencana dan terkoordinasi secara optimal dengan memperhatikan tujuan nasional dan regional (Sudjarwadi, 1987). UU No 11 Tahun 1974 Tentang Pengairan bertujuan untuk mengatur dan melaksanakan pengelolaan serta pengembangan sumber-sumber air dan jaringan-jaringan pengairan (saluran saluran beserta bangunan-bangunannya) secara lestari dan untuk mencapai daya guna sebesar-besarnya. Pada penelitian ini, asumsi pengembangan sumber daya air di DAS Yeh Penet diperuntukan untuk pemenuhan air baku PDAM dan SPAM Sarbagita. Gambaran secara umum tahapan penelitian Pengembangan Sumber Daya Air di Daerah Aliran Sungai Yeh Penet sesuai dengan Gambar 1.

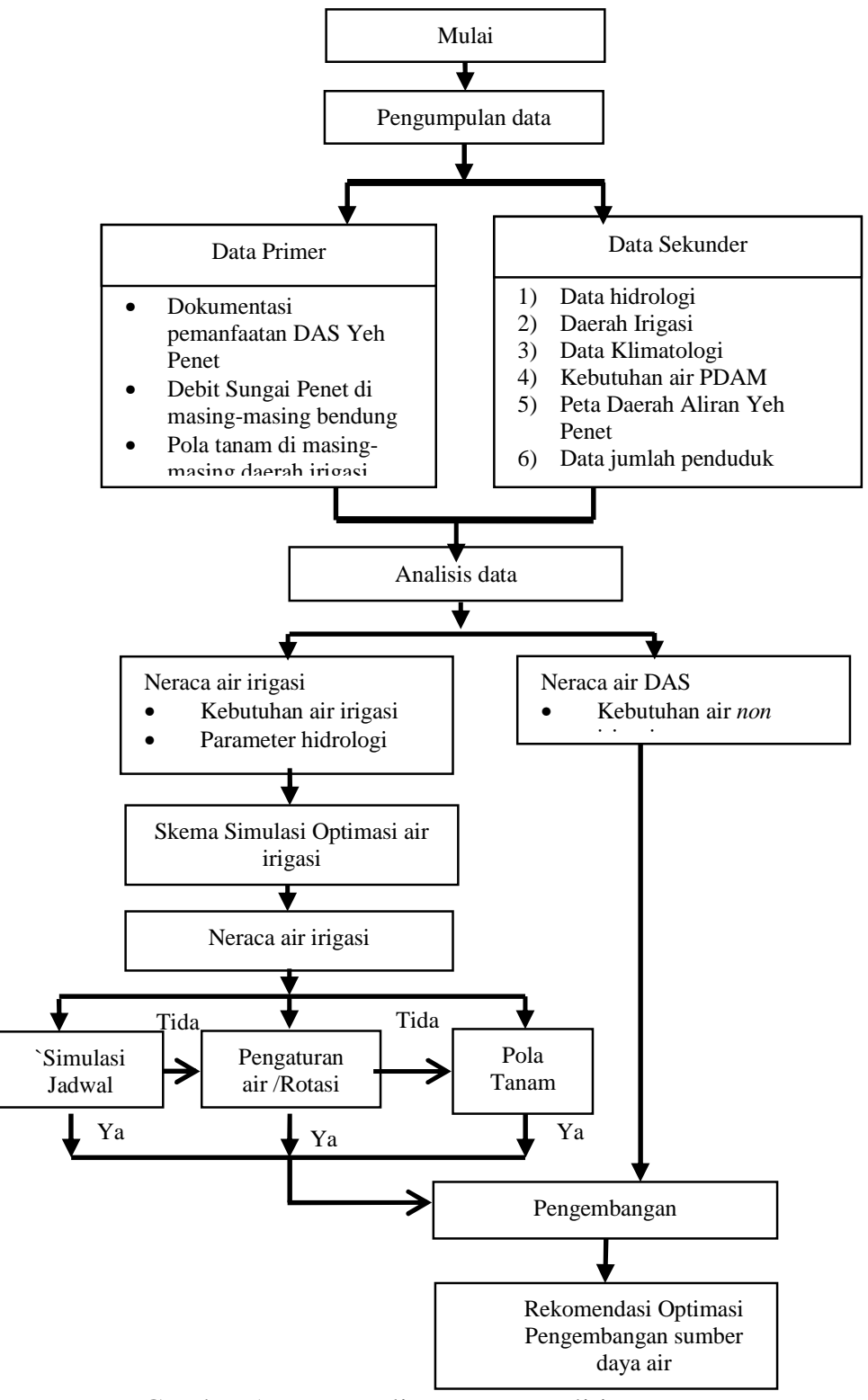

Gambar 1. Bagan alir proses penelitian

\section{HASIL DAN PEMBAHASAN}

Hasil analisis ketersediaan air

Ketersediaan air pada sungai Penet berdasarkan pencatanan di masing masing wilayah pengamatan adalah sebagai berikut 
a) DI Peneng debit terbesar $0.89 \mathrm{~m}^{3} /$ det pada bulan Maret dan terkecil $0.5 \mathrm{~m}^{3} /$ det pada bulan September

b) DI Luwuscarang sari debit terbesar 1.773 $\mathrm{m}^{3} /$ det pada bulan Maret dan terkecil 0.699 $\mathrm{m}^{3} /$ det pada bulan September.

c) DI Kacangan debit terbesar $0.86 \mathrm{~m}^{3} /$ det pada bulan Maret dan terkecil $0.19 \mathrm{~m} 3 /$ det pada bulan Agustus

d) DI Penarungandebit terbesar $4.09 \mathrm{~m}^{3} / \mathrm{det}$ pada bulan Januari dan terkecil $2.12 \mathrm{~m}^{3} / \mathrm{det}$ pada bulan Juli

e) DI Kapal debit terbesar $3.72 \mathrm{~m}^{3} /$ det pada bulan Maret dan terkecil $1.9 \mathrm{~m}^{3} /$ det pada bulan Juli

f) DI Munggu debit terbesar $6.23 \mathrm{~m}^{3} /$ det pada bulan Maret dan terkecil $0.96 \mathrm{~m}^{3} /$ det pada bulan Juli.

\section{Debit andalan}

Analisis debit andalan 80\% dengan tingkat ketidakpastian $20 \%$ dengan menggunakan metode Rangking, ketersediaan air di masing-masing DI sangat berfluktuatif. DI Kacangan terbesar 0.12 $\mathrm{m}^{3} /$ det s/d $0.45 \mathrm{~m}^{3} /$ det demikian juga pada DI Peneng $\left(0.42 \mathrm{~m}^{3} /\right.$ det s $\left./ \mathrm{d} 0.64 \mathrm{~m}^{3} / \mathrm{det}\right)$, DI LCS $(0.54$ $\left.\mathrm{s} / \mathrm{d} 0.939 \mathrm{~m}^{3} / \mathrm{det}\right)$, DI Penarungan(1.02 s/d 3.54 $\mathrm{m}^{3} /$ det $)$, DI Kapal (1.44 s/d $3.34 \mathrm{~m}^{3} /$ det) dan DI Munggu (1.13 s/d $\left.2.07 \mathrm{~m}^{3} / \mathrm{det}\right)$, seperti yang ditunjukan grafik 2 berikut ini:

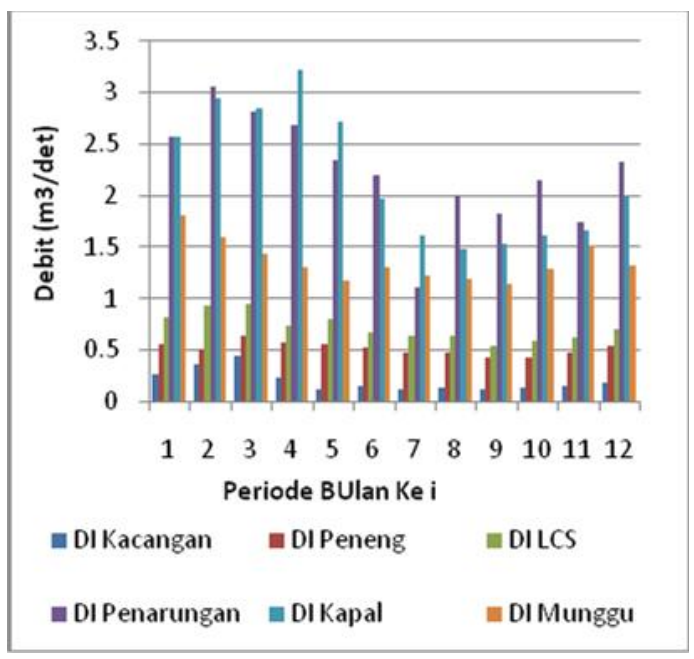

Gambar 2. Debit Andalan 80\% setiap DI DAS Penet (Sumber : hasil Perhitungan)

\section{Kebutuhan air irigasi}

Analisis kebtuhan air rerata dengan debit andalan $80 \%$ memberikan ktersediaan air yang positif. Namun, ketersediaan air dan pemakaian air irigasi per periode tengah bulanan sangat berfluktuastif. Tabel 2 menunjukan pemakauan air irigasi rerata dan ketersediaan debit andalan $80 \%$.
Tabel 2 Kebutuhan air irigasi dan Debit Andalan $80 \%\left(\mathrm{jt} \mathrm{m}^{3}\right)$

\begin{tabular}{|c|c|c|c|c|}
\hline \multirow[t]{2}{*}{$\begin{array}{l}\text { Daerah } \\
\text { irigasi }\end{array}$} & \multicolumn{3}{|c|}{$\begin{array}{l}\text { Rerata kebutuhan air } \\
\text { irigasi alternatif jadwal } \\
\text { tanam }\left(\mathbf{j t} \mathbf{~ m}^{\mathbf{3}}\right)\end{array}$} & \multirow{2}{*}{$\begin{array}{c}\text { Debit } \\
\text { andalan } \\
(\mathbf{8 0} \%) \\
\left(\mathbf{j t} \mathbf{~ m}^{3}\right)\end{array}$} \\
\hline & 1 & 2 & 3 & \\
\hline DI Peneng & 0.241 & 0.242 & 0.243 & 0.869 \\
\hline $\begin{array}{l}\text { DI } \\
\text { luwuscarang } \\
\text { sari }\end{array}$ & 0.688 & 0.672 & 0.686 & 0.939 \\
\hline DI Kacangan & 0.196 & 0.190 & 0.195 & 0.382 \\
\hline $\begin{array}{l}\text { DI } \\
\text { Penarungan }\end{array}$ & 0.294 & 0.281 & 0.287 & 2.928 \\
\hline DI Kapal & 0.896 & 0.875 & 0.903 & 2.860 \\
\hline DI Munggu & 0.959 & 0.929 & 0.988 & 1.787 \\
\hline
\end{tabular}

Sumber : Hasil Perhitungan

\section{Neraca air irigasi}

Neraca air pada Daerah Irigasi (DI) menunjukan ketersediaan air sisa pemanfaatan air untuk kepentingan irigasi. Ketersediaan air sisa pemanfaatan irigasi seperti ditunjukan pada gambar grafik 3 s/d 8 memberikan data ketersediaan air pada DI luwuscarang sari dan DI Kacangan dengan alternatif jadwal tanam tidak memberikan ketersediaan air sisa surplus. Sehingga analisis kebutuhan air irigasi pada DI Luwuscarang sari dan DI Kacangan mempergunakan teknik optimasi dengan pengaturan air dengna system 2 golongn di buka dan satu golongan di tutup dengan periode waktu tengah bulan untuk semua golongan. Pada DI Peneng, DI Psenarungan dan DI Kapal memberikan ketersediaan air yang surplus dengan mempergunakan pola tanam padi-padi-palawija. Pengembangan pola tanam pada DI Peneng, DI Penarungan, dan DI Kapal dapat dilakukan dengan mempergunakan pola tanam yang berbeda, namun harus memperhatikan kepentingan pada bagian hilirnya. Ketersediaan air pada DI Munggu dengan alternatif jadwal tanam dua memberikan ketersediaan air yang positif dibandingkan dengan alternatif satu dnegan tiga. Ketersediaan air pada DI Munggu minimum sebesar 0.25 juta $\mathrm{m}^{3}$ sampai dengan 1.51 juta $\mathrm{m}^{3}$.

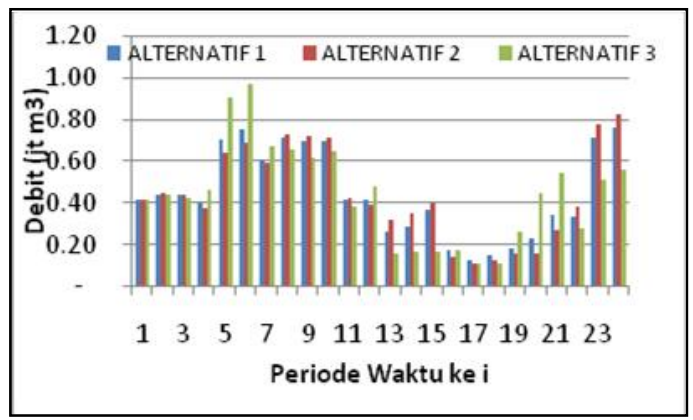

Grafik 3. Neraca Air DI Peneng (jt $\mathrm{m}^{3}$ )

(Sumber : hasil Perhitungan) 


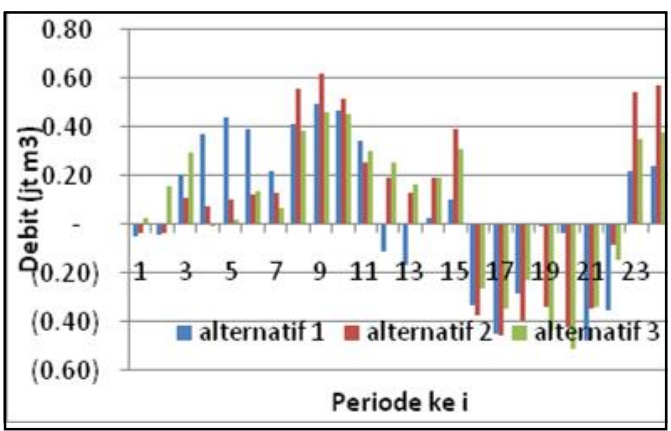

Grafik 4. Neraca Air DI LCS (jt $\mathrm{m}^{3}$ ) (Sumber : hasil Perhitungan)

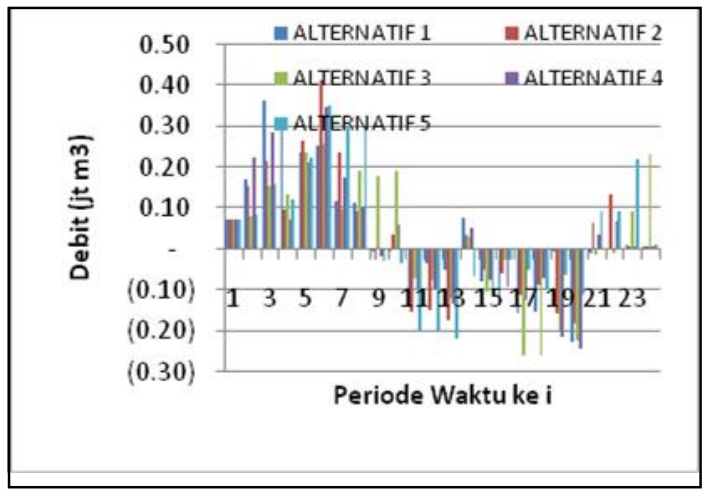

Grafik 5. Neraca Air DI Kacangan (jt $\mathrm{m}^{3}$ ) (Sumber : hasil Perhitungan)

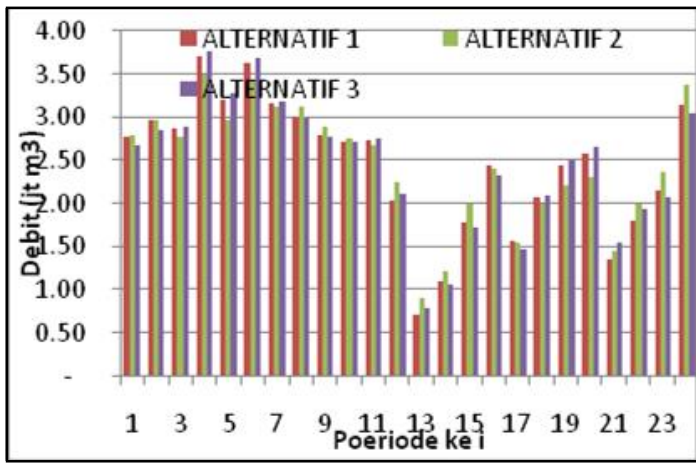

Grafik 6: Neraca Air DI Penarungan(jt $\mathrm{m}^{3}$ ) (Sumber : hasil Perhitungan)

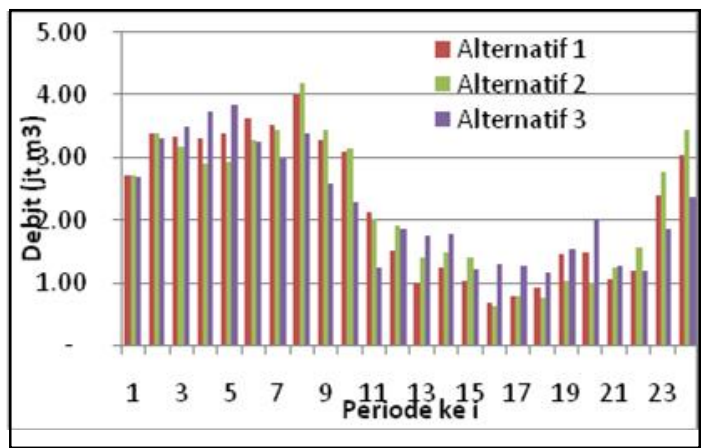

Grafik 7: Neraca Air DI Kapal (jt $\mathrm{m}^{3}$ )

(Sumber : hasil Perhitungan)

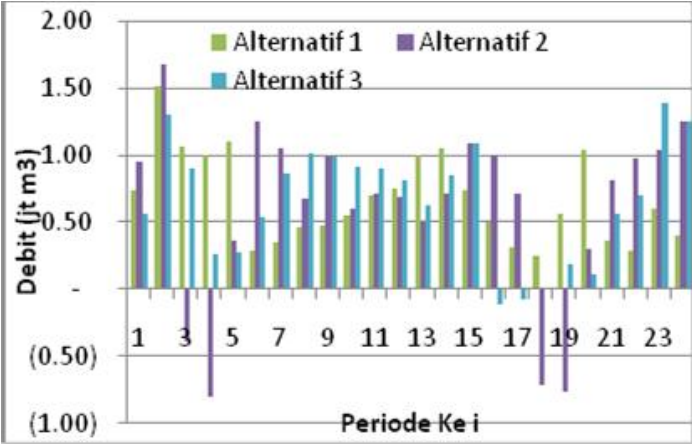

Grafik 8: Neraca Air DI Munggu (jt $\mathrm{m}^{3}$ ) (Sumber : hasil Perhitungan)

\section{Neraca Air DAS}

Neraca air DAS memberikan ketersediaan air sisa pemakaian air irigasi di DAS Yeh Penet minimum sebesar sebesar 0.25 juta $^{\mathrm{m} 3}$ (230liter/det) dan maksimum 1.51 juta ${ }^{\mathrm{m} 3}$ (1.092.36 liter/det) dengan rata-rata sebesar 0.67 juta $\mathrm{m}^{3} \quad(484.37$ liter/det). Ketersediaan air sisa pemanfaatan irigasi menunjukan imbangan debit DAS penet yang dapat dikembangkan untuk kpeerluan air baku PDAM.

\section{Kebutuhan air non irigasi}

Analisis kebutuhan air non irigasi mengacu pada pedoman Ditjen SDA Dep, Kimpraswil, 2003 dimana kebutuhan air domestik Kabupaten Badung sebesar 135 liter/kapita/hari, non domestik sebesar 40 liter/kapita/hari dan kehilangan air 45 liter/kapita/hari. Sedangkan kebutuhan air domestik Kabupaten Tabanan 120 liter/kapita/hari, kebutuhan non domestik 30 liter/kapita/hari dan kehilangan air sebesar 40 liter/kapita/hari. Kebutuhan air Kabupaten Badung dan Tabanan sesuai dengan tabel 3 dan tabel 4 . Berdasarkan data produksi Kabupaten Tabanan dan Kabupaten Badung maka proyeksi kebutuhan air untuk keperluan air baku sesuai dengan tabel 5 dan 6 .

Tabel 3 Kebutuhan air Domestik dan Non

\begin{tabular}{|c|c|c|c|c|}
\hline $\begin{array}{c}\text { Tahu } \\
\mathrm{n}\end{array}$ & $\begin{array}{c}\text { kebutuhan } \\
\text { air } \\
\left(\mathrm{m}^{3} / \text { hari }\right)\end{array}$ & $\begin{array}{c}\text { kebutuhan } \\
\text { air } \text { non } \\
\text { domestik } \\
\left(\mathrm{m}^{3} / \text { hari }\right)\end{array}$ & $\begin{array}{c}\text { Kehilang } \\
\text { an air } \\
\left(\mathrm{m}^{3} / \text { hari }\right)\end{array}$ & $\begin{array}{c}\text { Kebutuha } \\
\mathrm{n} \text { air total } \\
\left(\mathrm{m}^{3} / \text { hari }\right)\end{array}$ \\
\hline 2014 & $50,531.40$ & $12,632.85$ & $16,843.80$ & $80,008.06$ \\
\hline 2015 & $50,531.45$ & $12,632.86$ & $16,843.82$ & $80,008.13$ \\
\hline 2016 & $50,531.49$ & $12,632.87$ & $16,843.83$ & $80,008.19$ \\
\hline 2017 & $50,531.53$ & $12,632.88$ & $16,843.84$ & $80,008.26$ \\
\hline 2018 & $50,531.58$ & $12,632.89$ & $16,843.86$ & $80,008.33$ \\
\hline 2019 & $50,531.62$ & $12,632.91$ & $16,843.87$ & $80,008.40$ \\
\hline 2020 & $50,531.66$ & $12,632.92$ & $16,843.89$ & $80,008.47$ \\
\hline
\end{tabular}
Domestik Kab.Tabanan

Sumber : Hasil Perhitungan 
Tabel 4 Kebutuhan air Domestik dan Non Domestik Kab.Badung

\begin{tabular}{ccccc}
\hline Tahun & $\begin{array}{c}\text { Kebutuhan } \\
\text { Air } \\
\text { (m3/hari) }\end{array}$ & $\begin{array}{c}\text { Kebutuhan } \\
\text { Air } \text { non } \\
\text { Domestik } \\
\text { (m3/hari) }\end{array}$ & $\begin{array}{c}\text { Kehilangan } \\
\text { air } \\
\text { (m3/hari) }\end{array}$ & $\begin{array}{c}\text { Kebutuhan } \\
\text { Air total } \\
\text { (m3/hari) }\end{array}$ \\
\hline 2014 & $73,474.89$ & $21,770.34$ & $24,491.63$ & $119,736.86$ \\
\hline 2015 & $73,474.95$ & $21,770.36$ & $24,491.65$ & $119,736.96$ \\
\hline 2016 & $73,475.01$ & $21,770.37$ & $24,491.67$ & $119,737.06$ \\
\hline 2017 & $73,475.08$ & $21,770.39$ & $24,491.69$ & $119,737.16$ \\
\hline 2018 & $73,475.14$ & $21,770.41$ & $24,491.71$ & $119,737.26$ \\
\hline 2019 & $73,475.20$ & $21,770.43$ & $24,491.73$ & $119,737.36$ \\
\hline 2020 & $73,475.26$ & $21,770.45$ & $24,491.75$ & $119,737.46$ \\
\hline
\end{tabular}

Sumber: Hasil Perhitungan

Berdasarkan tabel 5 dan 6 kapasitas produksi dan kebutuhan air di Kabupaten Tabanan dan Kabupaten Badung menunjukan kebutuhan air untuk peningkatan layanan PDAM di Kabupaten Tabanan sebesar 350 liter/det dan Kabupaten Badung sebesar 575 liter/det. Sehingga pengambengan sumber daya air pada daerah aliran sungai Yeh Penet hanya mampu menyuplai kebutuhan air baku PDAM yang ada di kawasan sarbagita (Denpasar,Badung,Gianyar dan Tabanan) sebesar 0.67 juta $\mathrm{m} 3$ atau sebesar 484.37 liter/det dengan syarat dibuatkan waduk sebagai penampungan debit yang sangat berfluktuatif.

Tabel 5.Kapasitas produksi, Kebutuhan air baku Kab Tabanan

\begin{tabular}{|c|c|c|}
\hline $\begin{array}{l}\text { Kapasitas produksi } \\
\text { PDAM Tabanan }\end{array}$ & 484 & liter/det \\
\hline & $41,817.60$ & $\mathrm{~m}^{3} /$ hari \\
\hline \multirow[t]{2}{*}{ Kehilangan air } & $33.20 \%$ & \\
\hline & $13,883.44$ & $\mathrm{~m}^{3} /$ hari \\
\hline $\begin{array}{l}\text { Sisa produksi yang } \\
\text { tersalurkan }\end{array}$ & $27,934.16$ & $\mathrm{~m}^{3} /$ hari \\
\hline $\begin{array}{l}\text { Jumlah penduduk } \\
\text { (tahun 2010) }\end{array}$ & $420,370.00$ & jiwa \\
\hline $\begin{array}{l}\text { Kebutuhan } \\
\text { air/hari/kapita }\end{array}$ & 120 & liter/jiwa/hari \\
\hline Kebutuhan air total & $50,444.40$ & $\mathrm{~m}^{3} / \mathrm{hari}$ \\
\hline \multirow[t]{3}{*}{$\begin{array}{l}\text { Penduduk (Tahun } \\
\text { 2020) }\end{array}$} & 421,097 & jiwa \\
\hline & 120 & liter/jiwa/hari \\
\hline & $50,531.66$ & $\mathrm{~m}^{3} /$ hari \\
\hline Kekurangan air & $(22,510.24)$ & $\mathrm{m}^{3} / \mathrm{hari}$ \\
\hline $\begin{array}{l}\text { Kehilangan debit } \\
33.20 \%\end{array}$ & $(7,473.4)$ & $\mathrm{m}^{3} /$ hari \\
\hline Total kekurangan air & $(29,983.64)$ & $\mathrm{m}^{3} /$ hari \\
\hline $\begin{array}{l}\text { Rencana pengambilan } \\
\text { air }\end{array}$ & 350 & liter/detik \\
\hline Total pengambilan & $30,240.00$ & $\mathrm{~m}^{3} / \mathrm{hari}$ \\
\hline
\end{tabular}


4. Pengembangan debit DAS Yeh Penet untuk keperluan air baku PDAM sebesar 0,67 juta $\mathrm{m} 3$ sampai dengan 0,76 juta $\mathrm{m} 3(0,58$ $\mathrm{m} 3 /$ detik), namun belum mempu memenuhi kebutuhan air domestik, non domestik dan kehilangan air pada Kabupaten Tabanan (80.008,47 m3/hari) dan Kabupaten Badung (119.737,86 m3/hari)

\section{Saran}

Saran-saran yang diberikan sehubungan dengan penelitian ini adalah sebagai berikut:

1. Pola tanam dengan alternatif 2 dapat diterapkan untuk enam daerah irigasi di sepanjang DAS Yeh Penet karena memberikan kebutuhan air irigasi yang paling efisien dibandingkan dengan alternatif 1 dan alternatif 3

2. Pengembangan air baku pada DAS Yeh Penet tidak boleh lebih dari 534,81 liter/detik.

3. Kajian dengan jumlah data yang lebih banyak diperlukan untuk memberikan hasil yang lebih baik atau mendekati kondisi realita dilapangan.

4. Pada bagian hilir DAS Yeh Penet sebaiknya dibuatkan waduk atau reservoir yang cukup untuk menampung debit sungai yang berfluktuatif, sehingga dapat menyeimbangkan pengambilan untuk keperluan air baku PDAM atau sebagai SPAM Sarbagita. selain itu, perlu dilakukan kajian suplai air dari DAS Sungi untuk mengetahui ketersediaan air sisa pada bagian hilir DAS Yeh Penet.

\section{DAFTAR PUSTAKA}

Anonim. 2004. Undang-Undang No. 7 Tahun 2004 tentang Sumber daya air. Lembaran Negara RI Tahun 2004,Sekretariat Negara. Jakarta.

Anonim. 2005. Profile SWS Bali Penida, Direktorat Jendral Sumber Daya Air, Jakarta: Departemen Pekerjaan Umum

Anonim. 2009. Peraturan daerah Provinsi Balino 16 tahun 2009 tentang rencana tata ruang wilayah Provinsi Balitahun 2009-2029: Denpasar,Provinsi Bali

Asdak C. 1995. Hidrologi dan Pengelolaan Daerah Aliran Sungai, Gajah Mada University Press, Yogyakarta.

Arsyad S. 2006. Konservasi Tanah dan Air. Bogor : IPB Press.

Ditjen Pengairan. 1986. Standar Perencanaan Irigasi, Kriteria Perencanaan Bagian Jaringan Irigasi KP - 01 : Departemen Pekerjaan Umum.
Dirjen Cipta karya. 2010. Standar kebutuhan air: Departemen Pekerjaan Umum

Hatmoko, W. dan Triweko, W. (2011). Pengelolaan Alokasi air Pada Wilayah Sungai,Surakarta, Pusat Penelitian dan pengembangan Sumber daya air.

KLHS Provinsi Bali. 2010. Kajian Lingkungan Hidup Strategis Penglolaan Dan Pelestarian Sumber Daya Air Provinsi Bali. Jakarta: YIPD

availablefrom:http://www.klhsindonesia.org/ main/readpractice/klhs-pengelolaan-danpelestarian-sumber-daya-air-di-provinsi-balitahun-2010

Kompas. 2011. Bali Selatan Defisit Air, available from

http://regional.kompas.com/read/2011/08/20/0 7342521/ 2015. Bali.Selatan.Defisit.Air.Bersih

Loucks, D. P., J. R. Stedinger, and D. A. Haith., 1981. Water Resource Sistem Planning and Analisis, Prentice Hall Inc, Englewood Cliffs, New Jersey.

Nawasis. 2012. Badung Mulai Krisis Air available from http://www.nawasis.com/airminum/category/ instalasi\%20pengolahan\%20air/5

Nugroho,H. 2010. Aplikasi Hidrologi. Malang: Jogja Mediautama

Pasir,I W. 2010 Optimasai Pemanfaatan Air Waduk Telaga Tunjung(tesis). Denpasar: Universitas Udayana

Robert J.K, 2005, Pengelolaan Sumber Daya Air Terpadu. Yogyakarta: Andi

Siswanto. 2007. Operations Research. Jakarta: Erlangga

Sudjarwadi, 1987. Pola Operasi Pengaturan Waduk, PAU IT-UGM, Yogyakarta.

Sudjarwadi. 1999. Pengelolaan Sumberdaya Air Dalam Otonomi Daerah, Bahan Kursus Singkat Sistem Sumberdaya air Dalam Otonomi Daerah ke I, Jurusan Teknik Sipil FT UGM, Yogyakarta

Tratmojo, B. 2009. Hidrologi Terapan. Yogjakarta: Beta Offset

Walhi Provinsi Bali, ekploitasi sumber daya air di Provinsi Bali. available from http://www.voaindonesia.com/content/eksploi tasi-sumber-daya-air-di-bali-sebabkankrisis/1494836.html 